\title{
TEORI H SEBAGAI ILMU WAHYU DAN TURATS DALAM ISLAM
}

\author{
Roikhan \\ Universitas Islam Negeri Syarif Hidayatullah Jakarta \\ roikhan.ma@uinjkt.ac.id
}

\begin{abstract}
The concept of conventional found the form of $M$ theory that almost able to unite the dimensions of time and space, but it still leaves unclear structure and systematics of the concept itself. Islam in the Qur'an Surah al-Hijr [15]: 87 was able to interpret the dimensions of time and space by tiered meaning of significance 7 and Qur'an. H' Theory as a formula could be more better and more precisely, because it can synchronize with the symbols of root word of Islam. The Hahslm equation $H=A h$ (SLM) can be obtained by a single theory that is also based on values of Islam and derived from al-Qur'an the word of Allah. This God equation would be the answer for the conventional scientific development that based on empirical values together with science of Islam that based on the value of worship or intangible value. In the end, the human civilization is able to break through the impasse of united science that stagnates in order of different dimensions. And Islam will be recognized as a single formula in human thought.
\end{abstract}

Keywords: H'Theory, Hahslm, Qur'an, Islam, and Science

\begin{abstract}
Abstrak
Konsep konvensional ditemukan dalam bentuk teori H yang hampir mampu menyatukan dimensi ruang dan waktu, tetapi masih menyisakan struktur dan sistematika yang belum jelas. Ajaran Islam sebagaimana tertera dalam Al Qur'an Surah al-Hijr [15]:87 telah menafsirkan dimensi ruang dan waktu dengan makna berjenjang signifikansi 7 dan Al Qur'an. Teori H sebagai rumus bisa lebih baik dan lebih tepat, karena dapat melakukan sinkronisasi dengan simbol akar kata dari Islam. The Hahslm persamaan $H=A h$ (SLM) dapat diperoleh dengan teori tunggal yang juga didasarkan pada nilai-nilai Islam dan berasal dari al-Qur'an yang merupakan firman Allah SWT. Firman Allah SWT ini akan menjadi jawaban bagi pengembangan ilmu pengetahuan konvensional yang berdasarkan nilai-nilai empiris bersama-sama dengan ilmu pengetahuan Islam yang berdasarkan nilai ibadah atau nilai intangible. Pada akhirnya, peradaban manusia mampu menerobos kebuntuan bersatunya ilmu yang mandeg di urutan dimensi yang berbeda. Dan Islam akan diakui sebagai formula tunggal dalam pemikiran manusia.
\end{abstract}

Kata kunci: H’Theory, Hahslm, Qur'an, Islam, dan Sains 


\section{Pendahuluan}

Ilmu pengetahuan tertinggi tentang penyatuan beberapa teori dasar saat ini yang menjadi debut pakar fisika dunia adalah Teori M. ${ }^{1}$

Pengembangan dari konsep terakhir ini sering disebut sebagai penuh dengan spekulasi bahwa arah menuju ilmu pengetahuan yang lebih baik telah benar berada di jalur ini. ${ }^{2}$ Ilmu pengetahuan terkini hampir mencapai puncaknya dengan mulai mencari teori tunggal dari berbagai formula di antaranya merupakan gabungan dari beberapa teori dasar dalam ilmu pengetahuan. ${ }^{3}$ Dalam kehidupan makro kosmos, teori fisika dasar ini menjadi postulat bagi ilmu pengetahuan, yaitu terdapat 4 gaya yang akan selalu ada di setiap sistem maupun sub sistem kehidupan. Keempat gaya tersebut yaitu: gaya elektromagnetik, nuklir lemah, nuklir kuat, dan gravitasi. ${ }^{4}$ Para ilmuwan berkolaborasi menggabungkan Teori Gravitasi Relativitas Umum dengan Teori Fisika Kuantum untuk mewujudkan kebenaran Teori $\mathrm{M}$ yang merupakan gabungan dari model empat gaya tersebut. ${ }^{5}$ Bahkan para pakar dunia juga menyetujui bahwa pasti ada teori tunggal yang dicari selama 3000 tahun untuk mengetahui rancang agung alam semesta ini.

Teori $\mathrm{M}$ atau teori membran (dawai) merupakan teori yang mendeskripsikan adanya dimensi yang bertahap sampai pada sebelas tingkatan. ${ }^{6}$ Kemudian dianggap terlalu sulit dan

${ }^{1}$ Matsuo Sato, "Zariski 3-Algebra Model of M-Theory", Journal of Modern Physics (2013).

${ }^{2}$ Washington Taylor, $M$ (atrix) Theory: Matrix Quantum Mechanics As a Fundamental Theory (California: Institute For Theoritical Physics, 2001).

${ }^{3}$ S. Sayyid, Islam and Knowledge (Dakota: Science Publishing, 2015).

${ }^{4}$ A. Kumar dan T. Debroy, "Calculating of ThreeDimensional Electromagnetic Force Field During Arc Welding", Journal of Applied Physics (2003).

${ }^{5}$ Tommaso Benacchio dan Rupert Klein, "A Semihydrostatic Theory of Gravity-Dominated Compressible Flow". Journal of The Atmospheric Sciences (2015)

${ }^{6} \mathrm{M}$ J. Duff, "M Theory (The Theory Formerly Known As Strings", International Journal of Modern Physics (1996). ekstrim untuk dilanjutkan, karena menjadi kurang logis dan sistematis. Pada tahap ini, ketika komunitas konvensional sedang berupaya mencari jalan keluar ternyata Islam juga berusaha untuk keluar dari belenggu ilmu syariah dan perilaku. Walaupun secara sekilas dimungkinkan bahwa Islam juga sebenarnya mempunyai ilmu pengetahuan yang luar biasa menakjubkan. ${ }^{7}$ Hanya saja, kemandegan pemikiran tidak hanya dimonopoli oleh pengembangan Teori $\mathrm{M}$ saja, tetapi juga oleh ilmuwan Islam. Untuk itu dibutuhkan perspektif berbeda yang bisa jadi menjembatani antara posisi ilmuwan konvensional yang logis fisik dengan agamawan spiritualis yang intuitif non-fisik. Agama menyatakan bahwa semua ilmu pengetahuan berasal dari Allah Swt., yang terkodifikasi dalam al-Qur'an yang menyebutkan bahwa Islam adalah jawaban dari ilmu pengetahuan semesta alam sebagaimana tercantum dalam Surah an-Nahl [16] ayat 89 berikut ini:

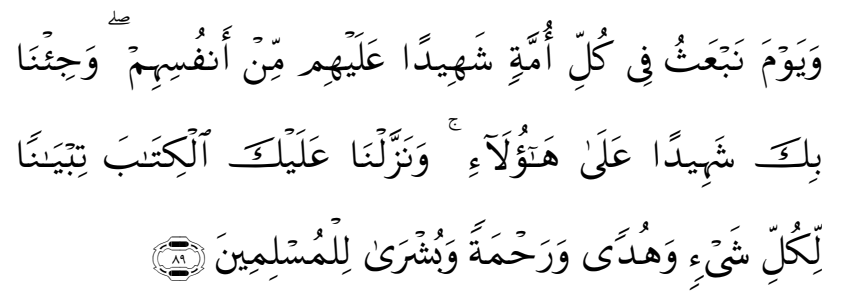

Artinya: "Dan Kami turunkan kepadamu Al Kitab (al-Qur'an) untuk menjelaskan segala sesuatu dan petunjuk serta rahmat dan kabar gembira bagi orang-orang yang berserah diri” (Q.S. an-Nahl [16]: 89).

Islam rahmatan lil alamin merupakan bagian integral dari pengejawantahan sistem kehidupan yang ada pada diri manusia, lingkungan sekitar, dan alam semesta yang bermakna bahwa semua kehidupan berawal dari konsep besar Islam. Dengan kata lain konsep

${ }^{7}$ Naresh Kumar, Che Rose, dan Raduan, The Impact of Knowledge Sharing and Islamic Work Ethic on Innovation apability (Malaysia: Emerald Group Publishing Limited, 2010). 
penciptaan awal adalah Islam.

Grand Unified Theory dan Islam sejatinya berjalan berdampingan yang bermakna bahwa Ilmu dan Islam pasti sesuai dengan fitrah serta nilai universal. ${ }^{8}$ Sehingga titik pusat dari puncak peradaban manusia adalah Islam. Dalam penelitian ini diungkapkan bahwa ilmu pengetahuan berawal dari Islam sebagai sebuah sistem yang menyeluruh dengan metode pendekatan sesuai kaidah Bahasa Arab, yaitu melihat kata Islam dalam format kata dasar yang terdiri dari 3 huruf konsonan yaitu: sin, lam, mim. Kemudian diformulasikan dalam fungsi rumus Islam yang disebut dengan Teori $\mathrm{H}$ dengan senantiasa berlandaskan pada filosofi dasarnya, yang terdiri dari ontologi pada Islam, epistemologi dalam kaffah, dan aksiologinya yang berpola 2 arah berupa peringatan dan kebaikan, sehingga dinyatakan bahwa munculnya Islam, membentuk konsep kaffah, yang dilakukan melalui peringatan dan kebaikan.

Keilmuan Islam harus memiliki landasan berpikir untuk diimplementasikan di lapangan sesuai dengan kemajuan ilmu pengetahuan pada saat ini. Diperlukan sinkronisasi antara teori yang berasal dari al-Qur'an dengan praktik yang terjadi di dalam simulasi dan teknologi modern, sehingga butuh adanya koridor berupa konsep besar dari ilmu dasar Islam itu sendiri.

Formulasi dari ketiga elemen dasar filosofis Islam di atas sinkron dengan pendekatan yang menghasilkan Teori $\mathrm{H}$ yang merupakan penjabaran dari kata dasar Islam itu sendiri. Metode tersebut dapat dikembangkan dalam kehidupan seperti pengembangan keilmuan yang berkaitan antara manusia dan Tuhan. Elemen pertama adalah Tuhan, kemudian elemen kedua adalah alam, dan umpan baliknya adalah ibadah, serta 2 elemen lainnya adalah jalan dan lurus. Formulasi Islam ini diturunkan dari al-Qur'an

\footnotetext{
${ }^{8}$ Edgar E. Escultura, "The Logic and Fundamental Concepts of The Grand Unified Theory", Journal of Modern Physics (2013).
}

Surat al-Hijr: [15]: 87, dan QS. Ali Imran [3]:19.

\section{Ontologi}

Ontologis dari konsep Kaffah adalah Islam. Bahwa sistem kehidupan yang ada pada diri manusia, lingkungan sekitar, dan alam semesta berawal dari konsep Islam. Dengan kata lain konsep penciptaan awal adalah Islam.

Kata Islam memiliki akar kata dari 3 huruf, yaitu huruf 's' atau sin, huruf ' 1 ' atau lam, dan

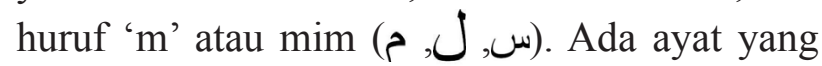
mendukung makna ontologis dari Islam yaitu pada QS. Ali Imran [3]: 19.

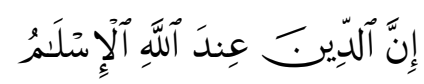

Artinya: Sesungguhnya Din di sisi Allah adalah Islam (Q.S. Ali Imran: 19).

\section{Epistemologi}

Islam dimaknai sebagai suatu sistem yang holistik, komprehensif atau menyeluruh. ${ }^{9}$ Kemudian Islam yang menyeluruh inilah yang menjadi epistemologi dari konsep institusi keuangan yang sedang dikembangkan, yaitu kaffah.

Institusi keuangan yang kaffah merupakan epistemologi yang muncul karena beranggapan bahwa konsep dasar kehidupan adalah Islam dan Islam dianggap sebagai suatu sistem. Epistemologi ini didukung oleh ayat alQur'an Surah al-Baqarah [2] ayat 208 yang berbunyi:

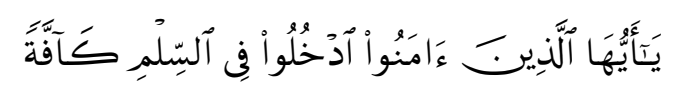
Artinya: "Wahai orang-orang yang beriman, masuklah kalian ke dalam Islam secara Kâffah (menyeluruh)" (Q.S. al-Baqarah [2]: 208).

${ }^{9}$ M. Burdbar Khan dan Naeem Nisar Sheikh, Human Resources Development Motivation and Islam (Morocco: Emerald Group Publishing Limited, 2012). 


\section{Aksiologi}

Diawali dari ontologis berupa Islam sebagai alasan kehidupan termasuk ekonomi, kemudian epistemologi yang digunakan adalah kaffah sebagai suatu sistem dalam institusi keuangan dan terakhir adalah aksiologi yang lebih sederhana berupa penerapan dalam pengembangan institusi, yaitu adanya keseimbangan dari 2 hal.

Dalam aksiologi ini, hubungan tersebut selalu ada 2 hal yang merupakan hubungan antara fungsi horizontal dan struktur vertikal. Munculnya Islam, membentuk konsep kaffah, yang memiliki 2 sisi berdampingan secara fitrah. ${ }^{10}$ Dua hal ini dianalogikan sebagai hal yang berbeda, seperti laki-laki dan perempuan, terang dan gelap. Sesuai al-Qur'an Surat Yasin [36] ayat 36 yang menyatakan 2 hal:

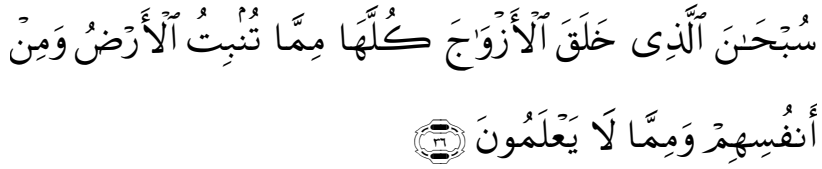

Artinya: "Maha Suci Tuhan yang telah menciptakan pasangan-pasangan semuanya, baik dari apa yang ditumbuhkan oleh bumi dan dari diri mereka maupun dari apa yang tidak mereka ketahui”' (Q.S. Yasin [36]: 36).

\section{Analisis Teori H}

Menurut Roikhan, Teori $H$ dapat didefinisikan sebagai berikut.

1. Secara sempit Teori $\mathrm{H}$ diartikan sebagai teori pola dasar tiga dominan dengan konteks tertentu dalam lima dimensi susunan invarian.

2. Secara luas untuk penggunaan paling umum Teori $\mathrm{H}$ dapat diartikan sebagai teori konsep dasar pola penciptaan dengan hubungan tertentu. H berasal dari rumus Hahslm, Qur'an surat Hijr, juga singkatan dari Huda atau Hidup.

Sedangkan makna teori $\mathrm{H}$ antara lain:

1. Sebuah himpunan utuh/sistem menyeluruh/ bagian terintegrasi akan terdiri dari 3 unsur

\footnotetext{
${ }^{10}$ Abbas J. Ali, Levels of Existence and Motivation in Islam (USA: Emerald Group Publishing Limited, 2015).
}

utama yaitu primer (pencipta/ intermediari), sekunder (ciptaan/ penerima), tertier (ibadah/ pemancar) yang bisa bermuatan positif atau negatif.

2. Tiga unsur tersebut akan memenuhi pernyataan bahwa sekunder di bawah primer akan melakukan tertier (manusia diciptakan Tuhan untuk ibadah).

Untuk mengetahui filosofi dari Teori $\mathrm{H}$ ini diperlukan pendalaman mengenai ontologinya yang selalu dikaitkan dengan Islam, baik secara harfiah maupun secara maknawi. Selanjutnya pengembangan secara epistemologi dalam institusi Islam yang kaffah menghadirkan terminologi baru menjadi suatu pendekatan lebih komprehensif. Secara umum, filosofi teori $\mathrm{H}$ bisa dianalogikan secara berurut bahwa latar belakang teori ini adalah nilai Islam dengan konsep yang menyeluruh melalui cara yang seimbang dengan mengejawantahkan makna ibadah dalam kehidupan.

Hal ini sesuai dengan isi al-Qur'an yang berbunyi 'silmi kâffah', dengan penjelasan bahwa kata 'silmi' merupakan derivasi dari huruf sin, lam, mim. Kata dasar sin, lam, mim ini secara umum merupakan salah satu solusi untuk menembus pengembangan konsep dalam rangka memecahkan permasalahan yang mendasar. Hal ini dirasakan perlunya suatu metode yang lebih baik untuk menjadi perimbangan dalam mengatasi keterbatasan metodologi dalam studi Islam.

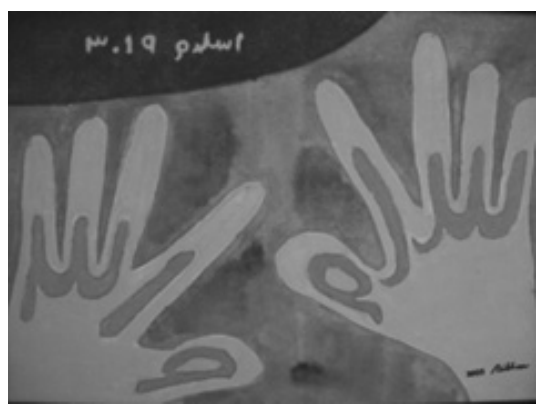

Gambar 1. Tulisan Islam Dalam Tangan Manusia $^{11}$

\footnotetext{
${ }^{11}$ Roikhan Mochamad Aziz, Sinlammim Kode Tuhan (Jakarta: Esa Alam, 2006).
} 
Hal ini juga sejalan dengan perkembangan peradaban terakhir yang menyatakan bahwa dirasakan perlu untuk mencari jalan tengah dari permasalahan institusi peradaban yang ada dengan beralih ke hal-hal yang berkaitan dengan spiritual. Semakin hari manusia semakin menginginkan pemikiran yang lebih baik, lebih tajam, dan mampu menjawab semua aspek. Hal ini akan menjadi dorongan pembuktian bahwa Teori $\mathrm{H}$ adalah juga mencakup pencarian jati diri keilmuan Islam yang paling sederhana yang dimulai dari tangan manusia.

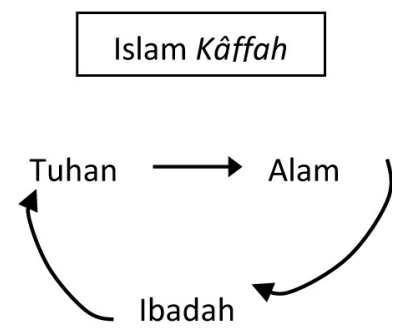

Gambar 2. Berpikir Kaffah dalam Islam ${ }^{12}$

Gambar berpikir kaffah dalam Islam di atas bermakna bahwa sebuah sistem yang menyeluruh pastilah bernilai Islam, sehingga sebuah sistem yang kaffah akan terdiri dari 3 bagian utama, yaitu Tuhan, Alam, dan Ibadah. Tiga variabel ini akan bermetamorfosis sesuai dengan konteks dari topik yang sedang difokuskan. Tetapi dasar pemikiran dari sebuah sistem atau sub sistem yang utuh haruslah terdiri dari 3 hal. Pendekatan Teori H dapat dikembangkan dalam kehidupan seperti pengembangan institusi ekonomi. Dengan merubah elemen pertama, yaitu Tuhan menjadi elemen ekonomi makro, kemudian elemen kedua adalah alam yang bisa dikonversikan menjadi elemen ekonomi mikro, dan feedbacknya adalah ibadah yang ditransformasikan menjadi peluang kehidupan berekonom.

Sesuai dengan kaidah Bahasa Arab, kata

${ }^{12}$ Roikhan Mochamad Aziz, "Kaffah Thinking On Sinlammim Method Through Digital Root", dalam Proceeding (Malaysia: UKM, 2009).
Islam berasal dari kata dasar 3 huruf konsonan: sin, lam, mim (J)(山)( (ل), kemudian mendapat awalan 1 huruf konsonan alif (I), sehingga terbentuk kata dasar alif, $\sin , \operatorname{lam}, \operatorname{mim}(\mathrm{a})(\mathrm{J})(\omega)(\mathrm{I})$.

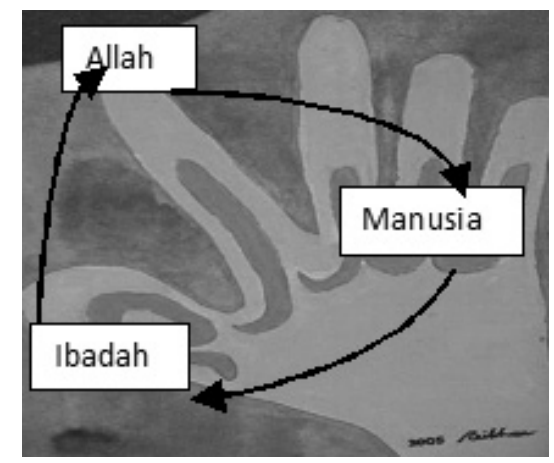

Gambar 3. Model Dasar Islam Kaffah ${ }^{13}$

Bentuk kata dasar yang terdiri dari 4 huruf (3 huruf +1 huruf) tersebut menjadi kata dasar utama untuk membentuk kata Islam. Kemudian bentukan kata dasar ini akan dituliskan dalam persamaan sederhana yaitu: Islam adalah alif, sin, lam, mim.

Fungsi 1

Islam $=$ Alif $($ Sin, Lam, Mim $)$

Di mana:

Islam=I, Alif $=$ A, Sin=S, Lam=L, Mim=M.

Rumus:

$\mathrm{I}=\mathrm{A}(\mathrm{S}, \mathrm{L}, \mathrm{M})$

Dari pernyataan di sisi Allah adalah Islam, diperoleh persamaan yang dituliskan secara sederhana, tetapi sebenarnya bukan persis mutlak sama, bahwa pendekatan persamaan hanya memberikan kemudahan dalam pembacaan rumus, seperti Allah 三 Islam, yang dibaca sebagai di sisi Allah adalah Islam. Analogi persamaan tersebut dibuat garis minus tiga yang menyatakan tidak persis sama, karena hanya untuk memudahkan pembacaan persamaan, yang sebenarnya harus dituliskan lengkap bahwa 'Din di Sisi Allah 三 Islam'.

Fungsi pertama di atas dapat dituliskan juga dalam persamaan latin atau dalam Greek Alphabet.

${ }^{13}$ Ibid. 
Fungsi 2

$\mathrm{I}=\mathrm{A}(\mathrm{S}, \mathrm{L}, \mathrm{M})$

$\mathrm{I}=\mathrm{A}(\Sigma, \Lambda, \mathrm{M})$

$\imath=\alpha(\Sigma, \lambda, \mu)$

Iota $=$ Alpha $($ Sigma, Lambda, $\mathrm{Mu})$

Dimana, $\mathrm{\imath}=$ Iota,$\alpha=$ Alpha, $\Sigma=$ Sigma,$\lambda=$ Lambda, $\mu=\mathrm{Mu}$.

Sekarang dari kata Islam diperoleh 4 variabel, yaitu alif, sin, lam, mim. Empat variabel ini akan dijadikan tolok ukur bagi pengembangan rumus lainnya. Ada ayat al-Qur'an Surat Al-Hijr [15]: 87 yang berbunyi:

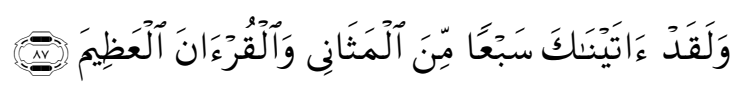

Artinya: "Dan Aku berikanmu 7 diulang dan Qur'an agung” (Q.S. al-Hijr: 87).

Dari Teori $\mathrm{H}$ di atas didapatkan rumus mengenai adanya dimensi waktu dan dimensi ruang. Secara implisit Allah Swt menyebutkan 7 diulang, kemudian peradaban manusia mengintepretasikannya 14 abad setelahnya sebagai simbol dari dimensi waktu dengan argumentasi adanya kata matsani atau diulang. Sedangkan al-Qur'an disimbolkan menjadi dimensi ruang yang terpecah lagi menjadi 4 bagian. Hal ini diinterpretasikan dari kata azhiim yang berarti dalam yang bermakna ruang. Dalam ilmu pengetahuan sudah dikatakan adanya dimensi ruang yang terbagi menjadi 4 gaya, yaitu gaya Elektromagnetik (E), gaya Nuklir Lemah $(\mathrm{N})$, gaya Nuklir Kuat (K), dan gaya Gravitasi $(\mathrm{G})$, yang disingkat menjadi $\mathrm{E}(\mathrm{N}, \mathrm{K}, \mathrm{G})$ yang secara analog disimbolkan sebagai bilangan $2(3,1,9)$.

Menurut Roikhan, dari ayat tersebut, didapatkan dua variabel utama, yaitu 7 (Tujuh) dan al-Qur'an. 7 (Tujuh) dianggap sebagai variabel mutlak, dan al-Qur'an masih dapat dipecah menjadi 2,3,1,9. Jika dijumlahkan, $2 \times 3 \times 19$ hasilnya adalah 114 . Sehingga didapatkan lima angka, yaitu 7,2,3,1,9. Untuk memudahkan dalam membuat rumus, angka-angka tersebut diubah, ke dalam huruf. Dalam penjelasan di atas dapat dilihat 7 menjadi A (Alif), 2 menjadi $h$ (hanif), 3 menjadi S (Sin/Manusia), 1 menjadi L (Lam/ Lillah) dan 9 menjadi M (Mim/ Masjid). Sehingga terbentuklah AhSLM. Untuk menjadikannya sebuah persamaan, dibutuhkan variabel dependen. Variabelnya yaitu H (Huda/ petunjuk). Huda didapatkan dari angka 4. Angka 4 , berasal dari penjumlahan $7+2+3+1+9=22$. (22) menjadi $2+2=4$. Akhirnya, terbentuklah sebuah persamaan yaitu $\mathrm{H}=\mathrm{A} \cdot \mathrm{h}(\mathrm{S}, \mathrm{L}, \mathrm{M})$. Apabila dianalogikan dalam kehidupan sehari-hari, A mencerminkan hubungan dengan komunitas, $\mathrm{h}$ mencerminkan hubungan dengan sesama manusia, S mencerminkan hubungan dengan diri sendiri, L mencerminkan hubungan dengan lingkungan, dan $\mathrm{M}$ mencerminkan hubungan etika. Variabel M inilah yang sulit dicari, dalam kehidupan.

Secara prosedural proses rekayasa teori $\mathrm{H}$ ini dilakukan dari pengumpulan data dari objek yang dijadikan sampel dalam implementasi teori ini.

1. Melakukan pendataan untuk memperoleh besaran dari objek yang akan ditinjau dalam nilai, harga, indeks, persentase, atau nominal yaitu dalam bentuk harga asli.

2. Meninjau laju besaran dari objek yang akan dihitung dalam skala persentase berupa selisih dari harga awal dengan harga berikutnya atau perbedaan dari besaran pertama dengan besaran kedua dan selanjutnya.

3. Membuat pola rata-rata dari objek yang akan ditinjau dengan perspektif teori ini dibandingkan dengan objek-objek lain yang sejenis atau meninjau posisi objek dikomparasi dengan rata-rata objek yang sejenis.

4. Setelah memperoleh nominal, laju, dan ratarata laju, selanjutnya dibutuhkan data lain dari objek yang sama berupa data yang bersifat intangible atau berkaitan dengan nilai religiusitas untuk didapatkan besaran bobotnya dibandingkan dengan obyek lain. Cara melakukan nilai bobot yaitu: 
a. Membuat rasio bobot berdasarkan data lain dari objek yang sama kemudian dibandingkan dengan bobot dari objek lain dengan data yang untuk diperoleh ranking atau urutan bobot antara objek utama dengan objek pembanding yang lain.

b. Selain menggunakan sumber data dari objek yang diteliti, dikombinasikan dengan expert adjustment/wawancara terstruktur dengan pakar sains yang memiliki otoritas untuk menilai bobot suatu objek.

c. Kemudian melakukan perangkingan objek berdasarkan bobot yang diperoleh dari berbagai sumber data tersebut, sehingga urutan tersebut juga merepresentasikan besaran bobot dari objek yang diteliti tersebut.

5. Selanjutnya setelah diperoleh data nominal, laju, dan bobot maka dilakukan penghitungan berupa perkalian dari data objek tersebut berupa: nominal x laju $\mathrm{x}$ bobot.

6. Setelah mendapatkan hasil dari perhitungan dari objek yang diteliti maka dilakukan perlakuan matriks untuk memperoleh kategori hasil sesuai format dalam hal ini objek akan dikategorikan dalam formasi straight, loads, dan impact:

a. Jika hasil positif adalah straight (jika minus adalah turn).

b. Jika hasil lebih besar dari 0,1 adalah load.

c. Jika hasil lebih besar dari rata-rata nilai berarti impact.

Perbedaan pendekatan antara rumus eksisting dengan rumus beracuan kitab suci adalah adanya faktor bobot. Pada pendekatan konvensional kategori hasil akan ditekankan dalam bentuk tangible atau nilai fisik yang tampak. Sedangkan pada pendekatan agama akan lebih menekankan intangibel atau perspektif yang lebih dari fisik, yaitu juga memasukkan nilai religiusitas atau ibadah. Walaupun jika didampingkan akan terlihat rumus yang sama, tetapi ketika implementasi terjadi deviasi hasil intepretasi. Keilmuan sekular akan mendasari pada segmen data implementatif atau empirik. Sedangkan keilmuan Islam akan senantiasa memasukkan tidak hanya empirik tetapi juga besaran religiusitas atau intangible value. Secara berdampingan dalam rumus konvensional versus Teori H diperoleh persamaan sebagai berikut:

Ciptaan $=$ Waktu, Ruang

Di mana,

Ciptaan $=\mathrm{C}$

Waktu $=\mathrm{W}$

Ruang $=\mathrm{R}$

Sehingga,

$\mathrm{C}=\mathrm{W}, \mathrm{R}$

Dan,

$\mathrm{R}=\mathrm{E}(\mathrm{N}, \mathrm{K}, \mathrm{G})$

Di mana,

$\mathrm{E}=$ Elektromagnetik

$\mathrm{N}=$ Nuklir Lemah

$\mathrm{K}=$ Nuklir Kuat

$\mathrm{G}=$ Gravitasi

Sedangkan Teori H memiliki persamaan:

Huda = Alif, hanif (Sin, Lillah, Masjid)

Di mana,

Huda $=\mathrm{H}$

Alif $=\mathrm{A}$

hanif $=\mathrm{h}$

Sin $=\mathrm{S}$

Lillah $=\mathrm{L}$

Masjid $=\mathrm{M}$

Sehingga,

$\mathrm{H}=\mathrm{A}, \mathrm{h}(\mathrm{S}, \mathrm{L}, \mathrm{M})$

Di mana,

$\mathrm{A}=7$

$\mathrm{h}=2$

$\mathrm{S}=3$

$\mathrm{L}=1$

$\mathrm{M}=9$

Kemudian, $\mathrm{C}=\mathrm{H}$

Dengan diketahui bahwa $\mathrm{W}=\mathrm{A}=7$ 
Sehingga

$\mathrm{R}=\mathrm{h}(\mathrm{S}, \mathrm{L}, \mathrm{M})=2(3,1,9)$

Kesimpulan bahwa:

$\mathrm{W}, \mathrm{E}(\mathrm{N}, \mathrm{K}, \mathrm{G})=\mathrm{A}, \mathrm{h}(\mathrm{S}, \mathrm{L}, \mathrm{M}) \ldots$

Rumus konvensional W,E (N,K,G) atau oleh sebagian fisikawan disebut sebagai Teori M, maka dalam Islam sudah punya rumus yang lebih baik dan lebih tepat, yaitu Teori H dengan sistematika lebih akurat.

Sesuai dengan firman Allah dalam al-Qur'an Surat al-Lail [92]: 5-7 yang berbunyi:

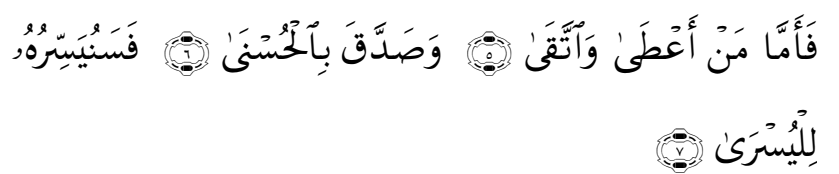

Artinya: (5). Maka siapa yang patuh dan tekun, (6). Dan membenarkan yang tepat, (7). Maka kami memudahkan dia dengan kemudahan" (QS. al-Lail [92]: 5-7).

Teori $\mathrm{H}$ ini merupakan konsep dari Allah yang bijaksana dan rumus yang tepat sehingga menjadi argumen bagi adanya rumus konvensional berupa Teori M. Sesuai dengan firman Allah dalm Qur'an Surat an-Nahl [16]: 125 yang berbunyi:

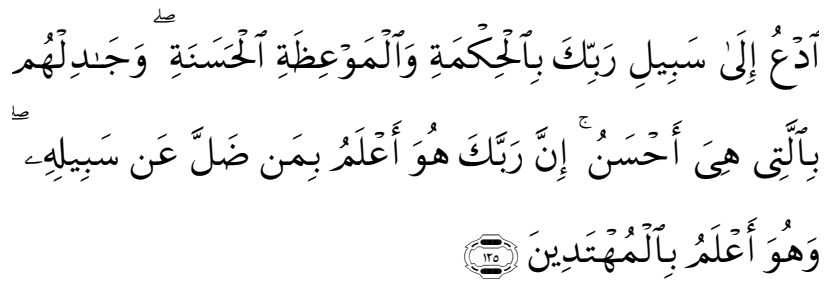

Artinya: "Serulah kepada jalan Rabb mи dengan bijaksana dan nasihat yang tepat dan bantahlan mereka dengan karakter yang dia lebih tepat. Sesungguhnya Rabb mu, Dia lebih mengetahui karakter siapa yan lupa dari jalan-Nya dan Dia lebi mengetahui karakter orang yang mendapat pengenalan" (QS. anNahl [16]: 125).

Pencarian teknologi semakin teliti hingga sudah sampai teknologi nano yang menjadikan ilmu pengetahuan semakin lebih baik dan lebih tepat dengan didasari oleh kitab suci, yaitu alQur'an. Jika sudah mencapai rumus yang sangat tinggi dan tajam, maka akan mudah untuk diketahui kesalahannya bila ada perbedaan sedikit saja. Jadi, jika ada rumus yang lebih baik dan lebih tepat, ternyata Allah sudah menjanjikan akan muncu kemudahan yang lebih akurat lagi.

\section{Kesimpulan}

Hasil penelitian dengan rumus dari alQur'an terutama surat al-Hijr [15]: 87 menghasilkan persamaan bahwa hasil ciptaan terdiri dari waktu dan ruang yaitu $\mathrm{H}=\mathrm{Ah}(\mathrm{S}, \mathrm{L}, \mathrm{M})$ yang juga sesuai dengan rumus konvensional, yaitu Teori $\mathrm{M}$ yang menyatakan bahwa ada dimensi waktu dan dimensi ruang yang terdiri dari 4 gaya tersebut. Sehingga persamaan konvensional dan Islam ini menjadikan Teori $\mathrm{H}$ sebagai tolok ukur baru dalam ilmu pengetahuan yang lebih baik dan lebih tepat karena sistematikanya yang berasal dari kitab suci alQur'an itu sendiri yang merupakan firman Allah Swt sebagai pencipta alam semesta ini.

Secara teknis rumus, perbedaan antara Teori $\mathrm{M}$ dengan Teori $\mathrm{H}$ adalah di variabel gravitasi dan ibadah. Dalam temuan empirik nilai gravitasi direpresntasikan dalam data tangible value, sedangkan temuan teoritis nilai ibadah direpresntasikan dalam data intangible value.

Pemodelan ini akan menjadi nano tekonologi ke depan disebabkan oleh keakuratannya yang berasal dari rumus Tuhan, untuk dapat menjembatani puncak ilmu pengetahuan yang akan dicapai manusia. Sehingga tujuan dari penelitian ini adalah untuk memberikan sebuah landasan teori berupa fungsi yang dapat dijadikan titik temu bagi kompleksitas ilmu pengetahuan terkini, dengan tetap mengacu pada kitab suci serta nilai universal yang diberikan oleh Allah Swt.

Teori H ini menjadi acuan baru dalam keilmuan Islam yang diilhami oleh al-Qur'an. Implikasi teoretis dari teori baru ini akan 
menambah khazanah teori dasar bagi pengembangan ilmu pengetahuan. Sehingga rujukan hard core theory tidak hanya dari teori barat atau teori konvensional saja, tetapi juga bisa merujuk ke teori Islam seperti teori $\mathrm{H}$.

\section{Daftar Kepustakaan}

Acsel, Amir. God Equation: Einstein, Relativity, and the Expanding Universe. New York: Random House, 1999.

Ali, Abbas J. Levels of Existence and Motivation in Islam. USA: Emerald Group Publishing Limited, 2015.

Bagir, et al. 2005. Integrasi Ilmu dan Agama: Intrepretasi dan Aksi. Bandung: Mizan, 2005.

Benacchio, Tommaso dan Klein, Rupert. "A Semihydrostatic Theory of GravityDominated Compressible Flow". Journal of The Atmospheric Sciences (2015).

Doebelin, Ernest O. System Dynamics: Modeling, Analysis, Simulation, Design. Cambridge: CRC Press, 1998.

Duff, M J. "M Theory (The Theory Formerly Known As Strings". International Journal of Modern Physics (1996).

Escultura, Edgar E. "The Logic and Fundamental Concepts of The Grand Unified Theory". Journal of Modern Physics (2013).

Forrester, Jay W. "Industrial Dynamics: A Major Breakthrough of Decision Maker". Editor Edward B. Roberts. Managerial Applications of System Dynamics. Cambridge: The MIT Press, 1981.

Forrester, Jay W. Principles of Systems. Cambridge: MIT Press, 1958.

Forrester, Jay W. System Thinking and Dynamic Modelling Conference: Learning Through System Dynamics as Preparation for the 21st Century. Concord: MIT Press, 1994.

Al-Fuyyumi, Ahmad ibn Muhammad Ali. AlMisbah al-Munir. Beirût: Maktabah Lubnan, 1987.

G \& C Merriam Co. Webster's New Collegiate Dictionary. New York: Collegiate, 1981.

Gie, The Liang. Pengantar Filsafat Ilmu. Jakarta: Liberty, 2004.

Hawking, Stephen. The Grand Design. Cambridge: Cambridge Press, 2010.

Isaacson, Walter. Einstein His Life and Universe. London: Pocket Books, 2008.

Jumin, Hasan Basri. Sains dan Teknologi dalam Islam. Jakarta: Rajawali Pres, 2012.

Al-Kahlânî, Muhammad Ibn Ismâ'il. Subul alSalâm. Bandung: Dahlan, t.th.

Khan, M. Burdbar dan Sheikh, Naeem Nisar. Human Resources Development Motivation and Islam. Morocco: Emerald Group Publishing Limited, 2012.

Kumar, A. dan Debroy, T. "Calculating of ThreeDimensional Electromagnetic Force Field During Arc Welding”. Journal of Applied Physics. American Institute of Physics (2003).

Kumar, Naresh, Che Rose, dan Raduan. The Impact of Knowledge Sharing and Islamic Work Ethic on Innovation Capability. Malaysia: Emerald Group Publishing Limited. 2010.

M. Quraish Shihab. Tafsir al-Misbah. Jakarta: Lentera Hati, 2002.

Al-Qur'ân al-Karim dan Terjemahnya. Lembaga Percetakan al-Qur'ân Raja Fahd, 2006.

Al-Qur'an dan Terjemahnya. Jakarta, Departemen Agama, 2003.

Roikhan Mochamad Aziz. Sinlammim Kode Tuhan. Jakarta: Esa Alam, 2006.

Roikhan Mochamad Aziz. Jejak Islam Yang Hilang. Jakarta: Sinlammim, 2007. 
Roikhan Mochamad Aziz. "Kaffah Thinking On Sinlammim Method Through Digital Root”. Proceeding. Malaysia: UKM, 2009.

Roikhan Mochamad Aziz. "The Mistery of Digital Root Based On Sinlammim Method". Proceeding. Bandung: Institut Teknologi Bandung (ITB), 2008.

Roikhan Mochamad Aziz. "The Root of Mathematics And Science Is Level Compared With Religious Thinking”. Proceeding. Jakarta: State Islamic University (UIN) Jakarta, 2008.

Roikhan Mochamad Aziz. "The Application of Mathematics In Information System Based On al-Qur'an". Working Paper, Studium General, State Islamic University (UIN) Jakarta, October 2008.

Richardson, George. Feedback Thought in Social Science and Systems Theory. Pennsylvania: Univ. of Pennsylvania Press, 1991.
Sato, Matsuo. "Zariski 3-Algebra Model of MTheory". Journal of Modern Physics (2013).

Sayyid, S. Islam and Knowledge. Dakota: Science Publishing. 2015.

Taylor, Washington. M(atrix) Theory: Matrix Quantum Mechanics As a Fundamental Theory. California: Institute For Theoritical Physics, 2001.

Al-Zarqa, Mustafa Ahmad. Al-Madkhal al-Fiqhi al-'Am. Vol.1. Beirût: Dâr al-Fikr, 1968.

Al-Zaydan, Abd al-Karim. Al-Madkhal li Dirazah al-shari'ah al-Islamiyyah. Beirût: Muassasah al-Risalah, 1989.

Al-Zuhayli, Muhammad. Marja' al-'Ulum alIslamiyyah. Damascus: Dâr al-Ma'rifah, 1992.

Zuhailî, Wahbah. al-Fiqh al-Islâm wa Adillatuhu. Terj. Jakarta: Bank Muamalat, 1999. 